\title{
GEOMORPHOLOGICAL RISKS AND ASSESSMENT OF ECOLOGICAL-GEOMORPHOLOGICAL SITUATIONS OF MINING REGIONS OF ARID ZONE OF KAZAKHSTAN
}

\author{
Roza BEXEITOVA (D)1, Omirzhan TAUKEBAYEV (D1,2,3* Asima KOSHIM(D)1, \\ Larysa VESELOVA (1) ${ }^{1}$, Aizhan ASSYLBEKOVA (1) 1 \\ ${ }^{1}$ Department of Cartography and Geoinformatics, Al-Farabi Kazakh National University, Almaty, Kazakhstan \\ ${ }^{2}$ Department of Mine Surveying and Geodesy, Satbayev University, Almaty, Kazakhstan \\ ${ }^{3}$ Earth Remote Sensing Center, Al-Farabi Kazakh National University, Almaty, Kazakhstan
}

Received 14 April 2020; accepted 17 August 2021

\begin{abstract}
The importance of the impact of emerging ecologic-geomorphological situations in areas of active mining development of Kazakhstan on the life of the population is difficult to overestimate in conditions of a dry climate, water scarcity and the use of outdated technologies for the extraction of solid minerals. This article examines the ecologic-geomorphological situations of mining areas of arid platform-denudation plains of Kazakhstan and gives their characteristics, which is based on an analysis of the leading natural and anthropogenically caused geodynamic processes, their spatial coverage, ratios and comparative assessment as an indicator of geomorphological risk within selected morphogenetic types of relief.
\end{abstract}

Keywords: solid minerals, arid zones, mining region, relief, ecologic-geomorphological situation, geomorphological risk, mapping.

\section{Introduction}

The analysis of the ecological and geomorphological situation and the assessment of geomorphological risks associated with anthropogenic activity is one of the main tasks of geoecology, and therefore causes great scientific and practical interest. The geomorphological environment is not static, it changes in time and space by geodynamic processes. Changes in this environment, caused by the activation of geodynamic processes and, accordingly, the redistribution of the products of destruction of rocks, are usually called geomorphodynamics. Undesirable geomorphodynamic situations can generate geomorphological risks, which, in this case, are designated as risks to human life and life, arising from damage caused by dangerous geodynamic processes and phenomena, both natural and anthropogenic in nature.

The objective of this study was to study the problem of the formation of dangerous geomorphological situations and associated geomorphological risks within the platform-denudation plains of the arid zone of Kazakhstan, the territory of which is rich in mineral resources and has been actively developed since the 30s of the XXth century. The main sources of deterioration of the geological and geomorphological environment and aggravation of geomorphological risks are metallurgical enterprises of international corporations like ArcelorMittal, Kazakhmys, Kazzinc and others and huge waste from their production. The relevance of the problem under study is caused not only by the fact that the ongoing mining of surface and underground character is the cause of the deterioration of the general environmental situation, the increasing potential of geomorphological risks in the region, but also the health of the population, which is a necessary basis for modern economic development of both Central and all Kazakhstan.

The problem of studying the ecological state of the geographic environment as a result of human intervention in the surface and near-surface structures of the earth's crust using various methods was dealt with by manyresearchers (Abalakov, 2007; Abalakov \& Kuzmin, 1998; Adamenko, 1991; Likhacheva et al., 2013; Grishin \& Novikov, 2000; Khotuntsev, 2004; Nysanbek, 2003; Bexeitova et al., 2016; Eszhanova, 2010; Simonov, 1990; Simonov \& Simonova, 2013; Korkin \& Talyneva, 2015; Milanovich, 2000; Toy, 1984; Charles et al., 1985; Shogren \& Grocken, 1999; Simonov \& Gladkevitch, 1995; Pecsi, 1986; Barsch, 1990; Gurney, 2005; Baborykin, 2013; Ermolov, 2014;

${ }^{*}$ Corresponding author. E-mail: omirzhan.taukebayev@gmail.com 
Kaiser et al., 2014; Voskresensky et al., 2018; Cheskidov et al., 2018; Kassymkanova et al., 2018; R. Bexeitova et al., 2018) many others.

\section{Study area}

The territory of the arid-platform zone of Kazakhstan is a unique geosystem located within the dry-steppe, semidesert and desert zones of the Kazakh shield of the UralSiberian epipaleozoic platform. The open structures of which are directly affected by natural and natural-anthropogenic processes and have a high mineral and raw material potential (Figure 1). In the northern part of the study region is located the Karaganda coal basin, coal mining in which has been carried out since the 30 s of the XX century. The pronounced continental climate characterized by high temperature amplitudes and a small amount of precipitation (150-350 $\mathrm{mm} /$ year) led to the dominance of subaridity and aridity of the natural environment with poorly developed vegetation cover and hydrographic network (Vilesov et al., 2009). The long-term resource-oriented orientation of the main economic sector of the region has led to the formation of a number of environmental problems, including geomorphological ones, characterized by stability due to their permanence and the increase in mining. Mining production in the study area, which requires large volumes of water, adequate infrastructure and is characterized by significant ground and underground mine workings and waste mass, has led to an imbalance of the regional geosystem - large changes in the geological and geomorphological environment and the formation of dynamic geomorphological risks, respectively, a sharp increase in load on all other natural ingredients (Bexeitova et al., 2018). The latter have low resistance to anthropogenic impacts and a high degree of accumulation of pollution, contributing to a significant deterioration of the ecological situation of the entire region. Particular damage concerns the soil cover, which in the mining areas is blocked by loose man-made deposits of dumps (Iskakov \& Medeu, 2006).

The area of direct mining of ores and coal within the Ulytau-Zhezkazgan, Temirtau-Karaganda, Balkhash-Sayak mining zones of the region is more than $960 \mathrm{~km}^{2}$, and taking into account all the serving infrastructure - more than $4600 \mathrm{~km}^{2}$ (Sakhiev, 2016).

The study of the ecological and geomorphological situation and the assessment of geomorphological risks was based on data from cartographic and bibliographic sources, long-term field studies (1988-2018), on the reporting and stock materials of industrial organizations and the determination of the relative assessment of the ecological state of the environment within mining zones.

\section{Data and methods}

The results of three-dimensional monitoring seismic surveying methods for studying deep geological heterogeneities, the structure and composition of ore objects, the dynamics of ore bodies and water beds during modeling and development of ore deposits in difficult mining and geological conditions and their effect on natural complexes in general and on internal and surface geodynamic processes are studied in particular (Cheskidov et al., 2018; Kassymkanova et al., 2018).

For the implementation of environmental and geomorphological situations, mountain-terrestrial areas of platform-denudation equal and the degree of geomorphological risks according to the results of many years of field observations (over 30 years) (Kochurov, 1997; Sturman, 2003; Asoyan et al., 2002) were studied.

Of the natural components, the main ones are directly the objects of study - the lithogenic basis, relief forms,

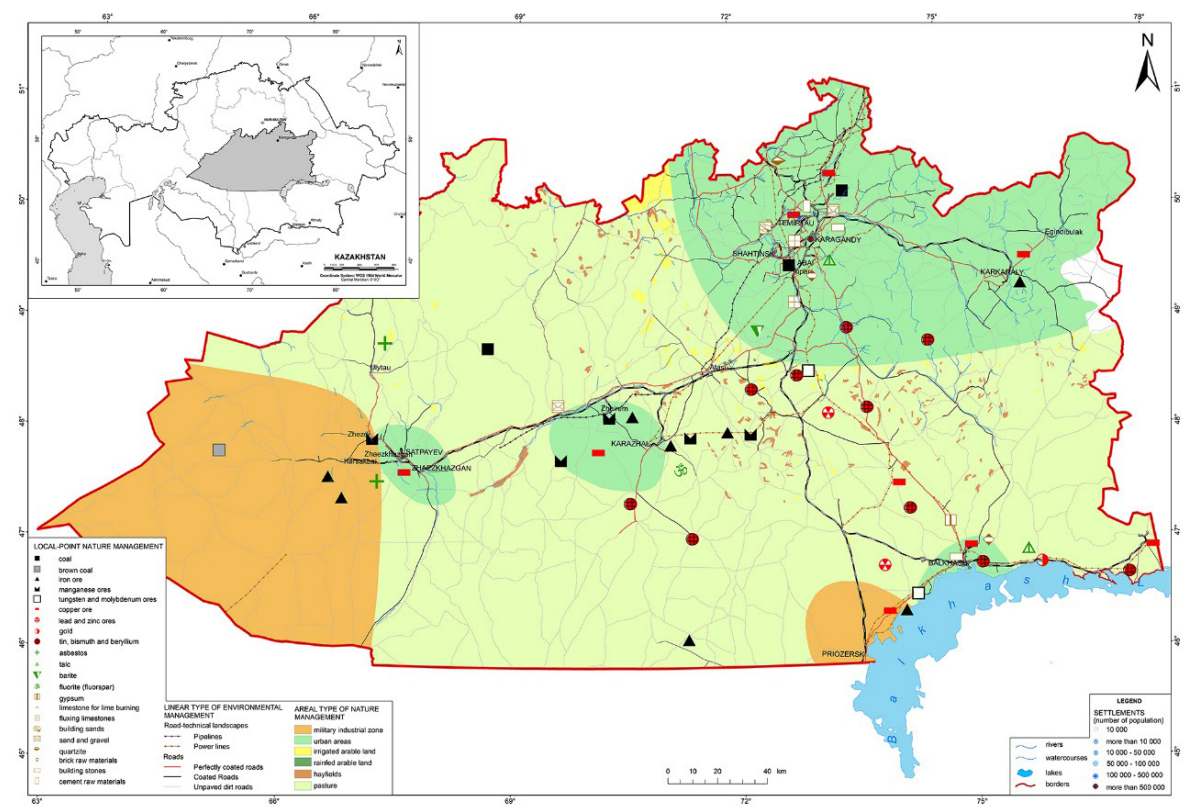

Figure 1. Map of natural and mineral resources (solid minerals) of Central Kazakhstan 
their types and morphogenesis processes that determine the current state of landscapes. From the group of socioeconomic indicators were selected, which are the resource basis of management, such as land, water resources. As well as the state of society, which is a consequence of the prevailing environmental situations, the result of which is the level of social tension and social development. According to these criteria, a social survey of the population was carried out within a representative age category (from 40 to 80 years) and a general comparative assessment of the ecological and geomorphological situation in the mining areas of the industrial zones of Central Kazakhstan was carried out (Table 1).
Modern mapping of geomorphological danger or risk is developing in different directions (urban planning, agricultural, geoecological) and at several territorial levels (global, national, regional, local and detailed) (Asoyan et al., 2002). In this work, we conducted a mapping of the geomorphological hazard of a geoecological orientation at the local level - the level of mining zones as key sections of the study area.

There are no methods for determining absolute estimates of the degree of danger of geomorphological processes in the scientific literature. Relative estimates of the degree of manifestation of the danger of a process are used. The degree of manifestation of geomorphological

Table 1. Criteria for assessing the ecological and geomorphological situations of mining regions of Central Kazakhstan

\begin{tabular}{|c|c|c|c|c|c|c|}
\hline \multirow{2}{*}{$\begin{array}{l}\text { Morphological } \\
\text { relief type }\end{array}$} & \multicolumn{2}{|c|}{$\begin{array}{l}\text { The coefficient of geomorphological } \\
\text { risk and the overall relative } \\
\text { assessment of the ecological- } \\
\text { geomorphological situation }\end{array}$} & \multicolumn{3}{|c|}{ Indicator groups } & \multirow{2}{*}{$\begin{array}{l}\text { The main directions } \\
\text { of improving the } \\
\text { ecological and } \\
\text { geomorphological state }\end{array}$} \\
\hline & $\begin{array}{l}\mathrm{C}_{\text {g.r. }} \text { and } \\
\text { relative } \\
\text { assessment }\end{array}$ & $\begin{array}{l}\text { Score (marked with } \\
\text { asterisks on the } \\
\text { map) }\end{array}$ & Nature and relief & Household & Social & \\
\hline $\begin{array}{l}\text { Piedmont } \\
\text { dissected } \\
\text { plains and } \\
\text { island } \\
\text { lowlands }\end{array}$ & $\begin{array}{l}C_{\text {g.r. }}=1.0 \\
\text { Satisfactory }\end{array}$ & $1\left(^{*}\right)$ & Norm & Norm & Norm & $\begin{array}{l}\text { Improvements are } \\
\text { possible without } \\
\text { significant cost. } \\
\text { Stabilization of the } \\
\text { structure of economic } \\
\text { activity }\end{array}$ \\
\hline $\begin{array}{l}\text { Denudation } \\
\text { plains of } \\
\text { various } \\
\text { morphology }\end{array}$ & $\begin{array}{l}\mathrm{C}_{\text {g.r. }}= \\
1.0-0.75 \\
\text { Weakly }\end{array}$ & $2(* *)$ & $\begin{array}{l}\text { Signs of changes } \\
\text { in individual } \\
\text { relief-forming } \\
\text { processes }\end{array}$ & $\begin{array}{l}\text { Individual } \\
\text { changes in } \\
\text { land use }\end{array}$ & $\begin{array}{l}\text { Awareness of } \\
\text { environmental } \\
\text { issues begins }\end{array}$ & $\begin{array}{l}\text { Land monitoring. } \\
\text { Improving land } \\
\text { use technologies - } \\
\text { agrotechnical measures }\end{array}$ \\
\hline $\begin{array}{l}\text { Accumulation } \\
\text { Plains }\end{array}$ & $\begin{array}{l}\mathrm{C}_{\text {g.r. }}= \\
0.75-0.55 \\
\text { Unfavorable }\end{array}$ & $3(* * *)$ & $\begin{array}{l}\text { Degradation } \\
\text { of individual } \\
\text { landscapes, } \\
\text { destruction of the } \\
\text { morpholithogenic } \\
\text { basis }\end{array}$ & $\begin{array}{l}\text { Decreased } \\
\text { land use } \\
\text { efficiency }\end{array}$ & $\begin{array}{l}\text { The mani- } \\
\text { festation of } \\
\text { environ- } \\
\text { mentally } \\
\text { determined } \\
\text { social stress }\end{array}$ & $\begin{array}{l}\text { Monitoring of geody- } \\
\text { namic processes both } \\
\text { in land and in un- } \\
\text { derground mining } \\
\text { of solid minerals. } \\
\text { The introduction of } \\
\text { new technologies } \\
\text { for the extraction } \\
\text { and processing of } \\
\text { solid minerals and } \\
\text { the improvement } \\
\text { of environmental } \\
\text { activities }\end{array}$ \\
\hline \multirow{2}{*}{$\begin{array}{l}\text { Dissected } \\
\text { denudation } \\
\text { and } \\
\text { accumulative } \\
\text { plains }\end{array}$} & $\begin{array}{l}\mathrm{C}_{\text {g.r. }}= \\
0.55-0.40 \\
\text { Critical }\end{array}$ & $4(* * * *)$ & $\begin{array}{l}\text { The formation of } \\
\text { new natural and } \\
\text { anthropogenic } \\
\text { forms and types } \\
\text { of relief }\end{array}$ & $\begin{array}{l}\text { Deterio- } \\
\text { rating land } \\
\text { and water } \\
\text { use effi- } \\
\text { ciency }\end{array}$ & $\begin{array}{l}\text { Ecological } \\
\text { situation as } \\
\text { a factor of } \\
\text { social tension } \\
\text { of social } \\
\text { development } \\
\end{array}$ & $\begin{array}{l}\text { Large material costs } \\
\text { for the restructuring } \\
\text { of certain parts of the } \\
\text { mining structure }\end{array}$ \\
\hline & $\begin{array}{l}\mathrm{C}_{\text {g.r. }}=0.40 \\
\text { Crisis }\end{array}$ & $5(* * * * *)$ & $\begin{array}{l}\text { Deep and } \\
\text { irreversible } \\
\text { relief changes, } \\
\text { landscape } \\
\text { degradation }\end{array}$ & $\begin{array}{l}\text { Strength- } \\
\text { ening } \\
\text { economic } \\
\text { losses. } \\
\text { Viola- } \\
\text { tions farm } \\
\text { structure }\end{array}$ & $\begin{array}{l}\text { Crisis } \\
\text { environmental } \\
\text { situation } \\
\text { as a factor } \\
\text { determining } \\
\text { social } \\
\text { development }\end{array}$ & $\begin{array}{l}\text { Fundamental } \\
\text { restructuring of the } \\
\text { economy, requiring } \\
\text { huge capital material } \\
\text { costs }\end{array}$ \\
\hline
\end{tabular}

Note: $\mathrm{C}_{\text {g.r. }}-$ Coefficient of geomorphological risk. Space circle with asterisks: ${ }^{\star}-$ green; ${ }^{\star *}-$ yellow; ${ }^{\star * *}-$ brown; ${ }^{\star * \star *}-$ deep orange; $* * * * *$ - red. 
risk is determined in the work as a coefficient (in points) according to field and cartographic measurements in points as the ratio of natural (denominator - natural processes) and active anthropogenic or technogenic processes (numerator - technological processes).

\section{Results and discussion}

Assessment of the ecological and geomorphological situation includes 5 gradations of the degree of manifestation of geomorphological risk: satisfactory (1 point), unfavorable ( 2 points), extremely unfavorable ( 3 points), critical (4 points), crisis (5 points). The main measures for their improvement are proposed for each of the gradations in assessing the state of ecological and geomorphological situations.

With a satisfactory estimate, improvements are possible without significant cost. Stabilization of the structure of economic activity. An unfavorable assessment of ecological and geomorphological situations requires the mandatory monitoring of land resources, improvement of land use technologies (agrotechnical measures). Given the extremely unfavorable state of ecological-geomorphological systems, it is necessary to monitor the geodynamic processes in both surface and underground mining of solid minerals, introduce new mining technologies and process solid minerals, and improve environmental protection. A critical assessment of the ecological-geomorphological state requires large material costs for the restructuring of certain parts of the structure of the mining economy, including the technology for the extraction of solid minerals. A crisis assessment requires a fundamental restructuring of the economy (up to the cessation of mining activity), which requires huge capital material costs.

The results of assessments of ecological and geomorphological situations of mining zones, their spatial position are reflected on maps of geomorphological risks and assessments of environmental and geomorphological situations of mining zones (Figures 1-3).

The basis and principles for determining geomorphological risks and their forecasting. The geomorphological risk or danger is determined by us, in contrast

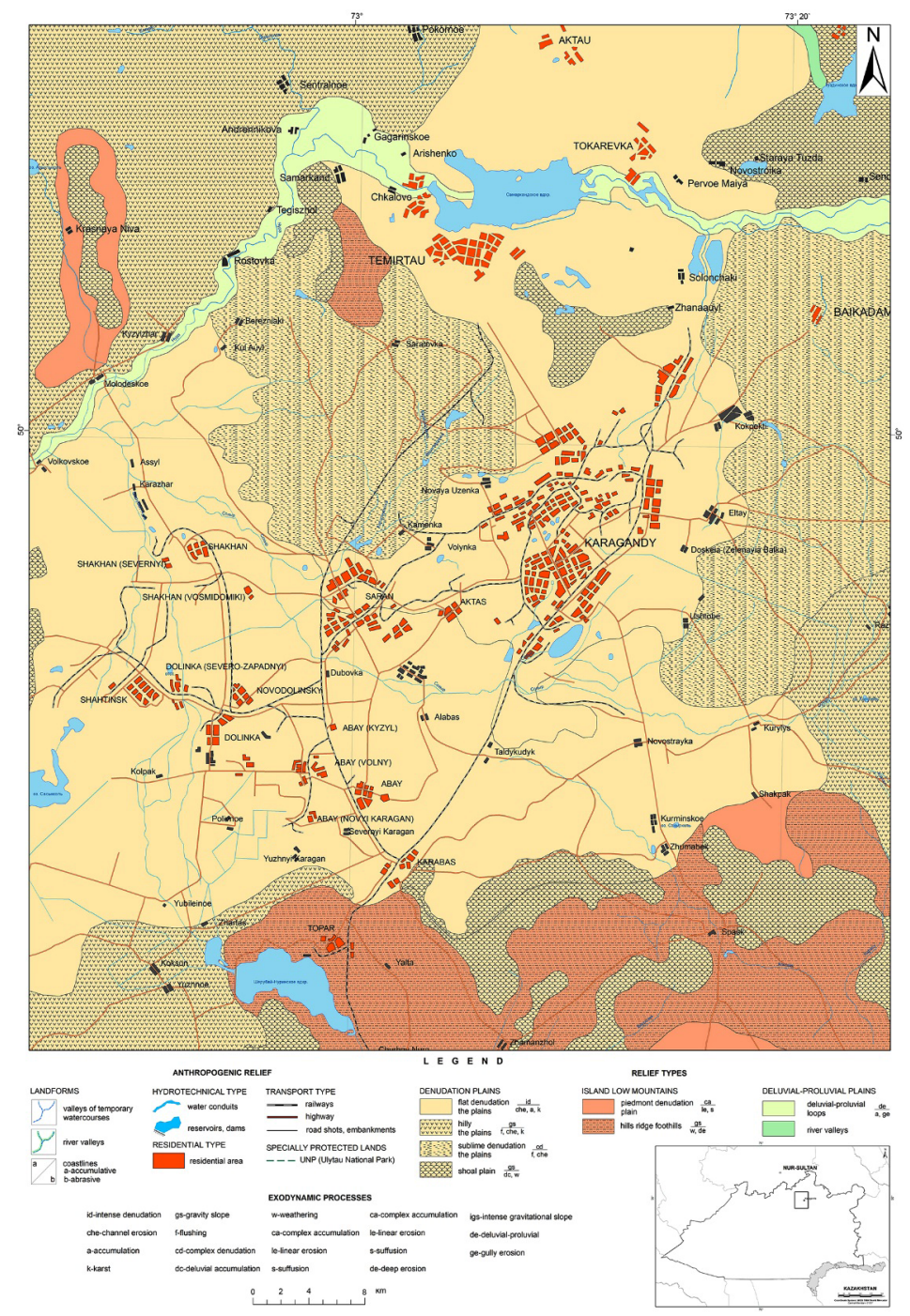

Figure 2. Map of Geomorphological risks and assessments of the ecological and geomorphological situation of the Temirtau-Karaganda mining zone 
to Likhacheva and Timofeev (2004) and others, as the likelihood of the onset (activation) of an undesirable geomorphological event (natural disaster) and the possible destruction of economic objects and the socio-economic system (Adamenko, 1991).

An undesirable geomorphological event or natural disaster is a natural phenomenon that is extraordinary in nature and leads to disruption of the normal life of people, destruction of material values. Natural disasters of a natural nature, including those provoked by anthropogenic activities, include phenomena associated with all spheres of the Earth. Such disasters as karst, landslides, erosion, earthquakes, including man-made nature, deflation, the formation of dirt and salt marshes (salinization), flooding and waterlogging are associated with the lithosphere within the study area. The relief, the nature of its development, the formation of its exodynamic processes, play an important role in assessing the environmental safety of the environment (Adamenko, 1991). This role is manifested in the form of various forms that are the result of various seismic technogenic and especially exogenous processes and phenomena that change the face of the environment, in general, and the geomorphological environment, in particular. Modern geomorphological processes in the areas of active mining development lead to a noticeable redistribution of rock masses and corresponding changes in the structure of the earth's surface (landslides, landslides, karst and seismic-technogenic dips, soil heaving and sedimentation, active water and salt erosion, wind erosion and accumulation, etc.) (Cheskidov et al., 2018; Kassymkanova et al., 2018; Bexeitova et al., 2018). As a result of these and other processes, a crisis geomorphological situation may arise - in other words, a geomorphological risk of a certain degree. In crisis situations associated with the negative phenomena of other terrestrial spheres, the relief plays a significant role as: 1) a pollutant concentrator in cases of linear movement, 2) a hazard diffuser (pollutants) during areal and frontal distribution, 3) a hazard trajectory changer, 4) a barrier on the path of the movement of flows of matter, including polluting.

The degree of danger of geomorphodynamics or geomorphological risk determines the degree of risk for that other entity, economic object, socio-economic system, when this object or system can greatly change or collapse under the influence of natural or anthropogenically provoked geomorphological processes. In environmental and geomorphological studies, mapping of geomorphological risk is practiced.

The main types and types of relief formation processes appearing in the study area - natural and active man-made (or anthropogenic-caused) processes and their correlations (within the selected types and subtypes of relief of

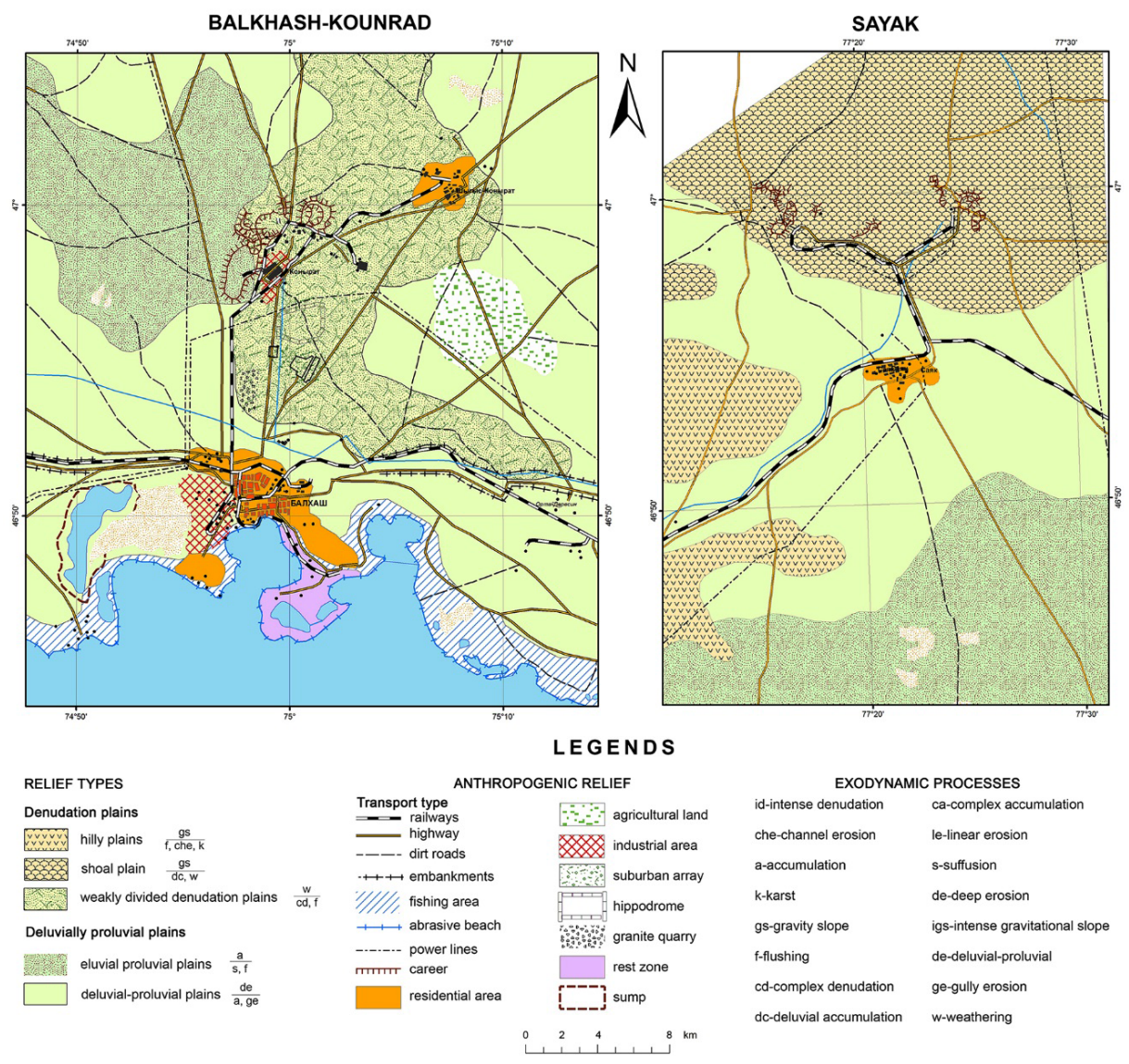

Figure 3. Map of geomorphological risks and assessments of the ecological-geomorphological situation of the Balkhash-Sayak mining zone 
the studied territory), which served as the basis for determining the geomorphological risk coefficients, are given in the table form.

Mapping geomorphological risks.

The cartographic models of geomorphological risks of key areas (Figures 1-3) were based on previously compiled geomorphological maps for Ulytau-Zhezkazgan, Temirtau-Karaganda and Balkhash mining zones. The choice of these zones is due to the high degree of activity of mining developments within them. Directly mapping the geomorphological hazard of the zones in question was preceded by an analysis of the scientific literature, cartographic material and reporting data on the types of mining activities and related anthropogenic and naturalanthropogenic processes, the impact of these processes on the living environment of the population and on the formation of the degree of geomorphological hazards or risks.

To identify the dynamics of environmental changes and the impact of these changes on living conditions, it was carried out in 2012-18 social survey of the population within the age category from 40 to 70 years, i.e. among people remembering the changes in the environment caused by climatic and anthropogenic factors. In quantitative terms, there are very few people over 70 years old - within $1 \%$ of the total number of respondents, so they were not included in the overall analysis. Residents of the cities of Zhezkazgan, Satbayev, Karaganda, Temirtau, Saran, Shakhtinsk and Balkhash were selected as respondents, of which indigenous people are over the age of 45-50. People under the age of 40-45 are more mobile than older people. In total, 240 people were interviewed in all cities of the region. For further analysis of the results of the social survey, the questionnaire questions were combined into 4 groups according to their content (Figure 4):

What changes have occurred in the climate, waters (surface, underground), in the snow cover, in the frequency of dust storms (the answers to them in the diagram are marked in blue);

What changes have occurred in the land cover and the nature of agricultural land use (the answers to them in the diagram are marked in brown);

What dangerous processes and phenomena (landslides, landslides, dips, erosions, salinization, deflation) were observed in your territory and what was the reason for that (the answers to them are marked in gray in the diagram);



Figure 5. Dynamics of negative exodynamic processes

Which PI deposits were developed and are being developed now, what measures are being taken for restoration (to improve the condition of the used land) (the answers to them are marked in yellow in the diagram).

The data were grouped by two adjacent years (2012-2013, 2014-2015, 2016-2017, and 2018-2019), their changes and dynamics are shown in the lower graph (Figure 5).

The results of the analysis of the social survey of the population, in general, showed an increase in destructive exodynamic processes (failures, caving in, flooding, suffusion, karst, etc.) in the areas of extraction and processing of solid minerals (Figure 6).

Spatial analysis of leading natural and anthropogenically determined processes and their relationships, grouped according to a 5-point system into geomorphological risk coefficients, are presented as follows (Table 1):

1. Within the natural background - no more than 1.0;

2. Low risk - 0.75-1.0;

3. The risk is moderate $-0.55-0.75$;

4. Significant risk - 0.40-0.55;

5. The risk of a dangerous degree is less than 0.40 .

Cartographic models of geomorphological risks are the basis for the development of recommendations for the prevention of geomorphological hazards and the restoration of the relief of the earth's surface of the study area. The main provisions of the research work in the UlytauZhezkazgan mining zone and recommendations for the prevention of environmental and geomorphological crisis situations were reported at the Scientific and Technical Council of the South Zhezkazgan ore district and adopted for further implementation in the work plan for optimizing the development of the ore field and the reclamation of developed lands.
Survey results of respondents under the age of 50



Questioning results of respondents under the age of 50 to 70 years

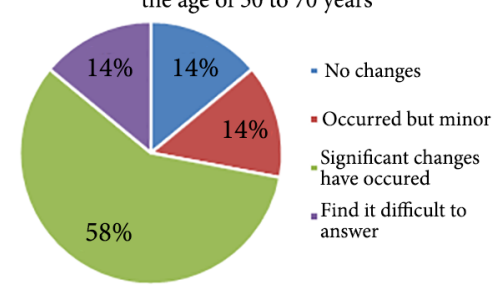

Survey results of respondents under the age of 70

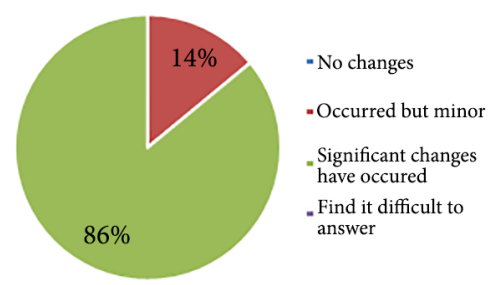

Figure 4. Chart of population survey results 

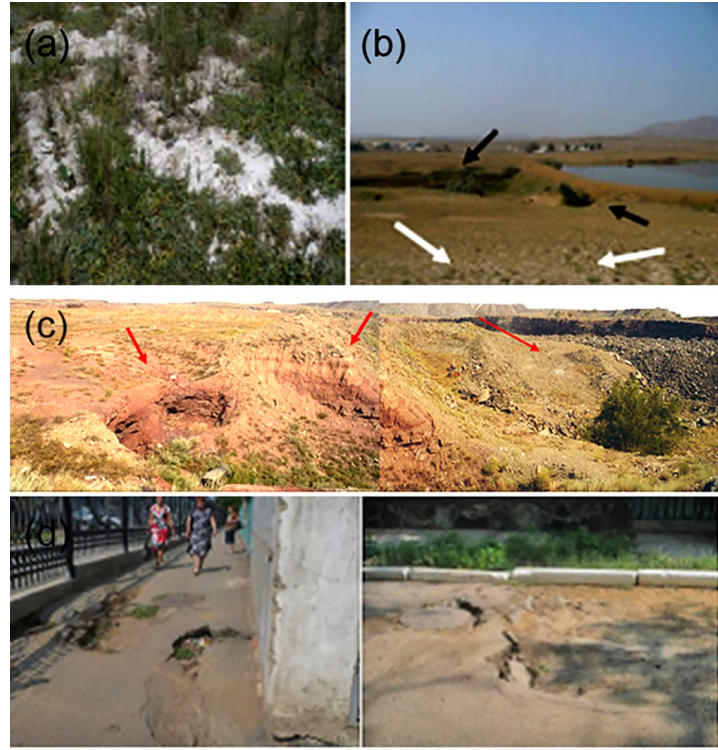

(e)



(f)

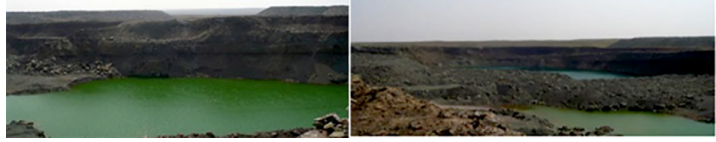

Figure 6. Manifestations of destructive exodynamic processes in the mining zones of Central Kazakhstan: a - salinization and degradation of the soil and vegetation cover (near the village of Ulytau, 2017); b - Failures over karst voids and degradation of vegetation as a result of long-term cattle grazing (Ulytau village, 2016); c - Dips over mine voids (a dark discharge wall is visible in the background) near the village of Rudnik (Satpayevsky mining and industrial area), 2014; d - Dips in asphalt pavement within urban areas as a result of leaching of fine earth in the basin zones of the Kengir and Nura rivers, 2014; e - Large mountain pit (pit depth reaches more than 90 m) Near the city of Satpayev (satellite city of Zhezkazgan) - a source of environmental pollution of the Satpayev mining and industrial region, 2016; f - Numerous abandoned quarries

filled with groundwater (Zhezkazgan industrial zone, 2016); g -

Loose deposits of dumps scattered around the perimeter within and outside the Temirtau-Karaganda mining and industrial zone, 2016

\section{Conclusions}

Ecological degradation of the geomorphological environment of Central Kazakhstan, caused by technogenic activities, has acquired a dangerous regional character. Of particular danger to the geomorphological environment is the development of geodynamic processes that enhance the natural and technological desertification and land degradation.
A review of the main natural and anthropogenic processes of the study area showed that there are certain differences in their manifestation depending on the geological and structural basis, morphogenetics of the relief and nature, scale and time of development of minerals. The basis for determining the degree of geomorphological risk for the mining regions of Central Kazakhstan - UlytauZhezkazgan, Temirtau-Karaganda and Balkhash - was taken as the ratio of the leading natural and anthropogenic caused negative processes.

A comparative ball estimate of the ratio of the leading natural and anthropogenically determined negative processes is given by morphogenetic sections of the relief and reflected in cartographic models, the basic content of which is the latest information on the spatial distribution of the main types and subtypes of relief and the prevailing exodynamic processes in areas of active mining.

\section{Acknowledgements}

The authors appreciate all the citizens who participated in the social survey for their support.

\section{Funding}

There were no funding from external source. The authors used their personal funds to finance this research.

\section{Authors' contributions}

Conceptualization, R.B.; methodology, R.B., A.K. and L.V.; software, O.T. and A.A.; analysis, R.B.; writing - original draft preparation, R.B., and O.T. All authors read and approved the final manuscript.

\section{Disclosure statement}

The Principal Author and co-authors, declare that there is no any potential conflict of interests in this work. The work does not infringe any copyright, proprietary right or any other right of any third party; and the Author and co-authors are the sole owners of the work.

\section{References}

Abalakov, A. (2007). Ekologicheskaya geologiya. Izdatel'stvo Irkutskovo gosudarstvennovo universitetata. http://window.edu.ru/resource/995/55995/files/Abalkov.pdf

Abalakov, A., \& Kuzmin, S. (1998). Ekologicheskaya ocenka ekomorfosistem. Geoekologiya, 3, 28-40.

Adamenko, O. (1991). Rol' i mesto izucheniya vzaimodejstviya geomorfologicheskih processov i okruzhayushchej sredy $\mathrm{v}$ ekologicheskom monitoringe. In O. Adamenko, Geomorfologicheskie processy i okruzhayushchaya sreda (pp. 4-8). Izdvo Kazanskogo GU.

Asoyan, D., Likhachyova, E., Timofeev, D., Barshhevskij, N., Borsuk, O., Borunov, A., Bronguleev, V., Zhidkov, M., Kozlova, A., Korzhuuv, S., \& Makkaveev, A. (2002). Rel'ef sredy' zhizni cheloveka (e'kologicheskaya geomorfologiya). Moscow. 
Baborykin, M. (2013). Monitoring opasnyh geologicheskih processov na linejnyh ob'ektah. Inzhenernye izyskaniya, 10-11, 44-55.

Barsch, D. (1990). Geomorphology and geoecology. Geomorphology New Folge, 79, 39-49.

Bexeitova, R., Veselova, L., Kassymkanova, Kh., Jangulova, G., Baidauletova, G., Zhalgasbekov, Y., Burlibayeva, Sh., \& Turekhanova, V. (2018). The problem of environmental safety of the fields of mining industrial production of arid zone of Kazakhstan. Geodesy and Cartography, 44(4), 146-155. https://doi.org/10.3846/gac.2018.4314

Bexeitova, R., Veselova, L., Duysebaeva, K., Bayandinova, S., \& Bekkulieva, A. (2016). Antropogennye faktory rel'efoobrazovaniya $\mathrm{v}$ predelah platformenno-denudacionnyh ravnin aridnoj zony Kazahstana (Central'nyj Kazahstan). Vestnik KazNU, ser. Geograficheskaya, 13-20.

Charles, J., Hughes, D., \& Burford, D. (1985). The effect of a rise water table on the settlement of backfill of Horsley restored opencast coal mining site, 1973-1983. In Third International Conference on Ground Movements and Structures (pp. 45-59). Cardiff, UK.

Cheskidov, V., Lipina, A., \& Melnichenko, I. (2018). Integrated monitoring of engineering structures in mining. Eurasian Mining, 2, 18-21. https://doi.org/10.17580/em.2018.02.05

Ermolov, A. (2014). Issledovanie opasnyh ekzogennyh geologicheskih processov v ramkah kompleksnyh inzhenernyh izyskanij i proizvodstvennogo monitoringa na linejnyh ob’ektah. Inzhenernye izyskaniya, 12, 39-40.

Eszhanova, A. S. (2010). Klassifikaciya ekzogennyh processov $\mathrm{v}$ svyazi s ocenkoj geomorfologicheskogo riska. Vestnik $\mathrm{Ka}$ $z N P U$. Almaty, 23-24.

Grishin, A., \& Novikov, V. (2000) Ekologicheskaya bezopasnost'. Uchebnoe posobie. Grand.

Gurney, S. (2005). Mapping the spatial distribution of geomorphological processes in Okstindan area of northern Norway, using Geomorphic Proces Units as derived from remote sensing and ground survey. Fennia, 1, 10-14.

Iskakov, N. A., \& Medeu, A. R. (Eds.). (2006). Prirodnye usloviya i resursy (T. 1, pp. 222-327). Print-S, Almaty.

Kaiser, A., Neugirg, F., Rock, G., Müller, C., Haas, F., Ries, J., \& Schmidt, J. (2014). Small-scale surface reconstruction and volume calculation of soil erosion in complex Moroccan gully morphology using structure from motion. Remote Sensing, 6(8), 7050-7080. https://doi.org/10.3390/rs6087050

Kassymkanova, Kh., Jangulova, G., Bekseitova, R., Miletenko, N., Baidauletova, G., Turekhanova, V., Zhalgasbekov, Y., \& Shmarova, I. (2018). Express-assessment of geomechanic condition of the rock massive and development methods of its strengthening and reinforcing for safe ecological developing of the fields of mineral resorces in hard mountain-geological and mining engineering conditions. News of the National Academy of Sciences of the Republic of Kazakhstan. Series of geology and technical sciences, 5(431), 37-47.
https://doi.org/10.32014/2018.2518-170X.33

Khotuntsev, Yu. (2004). Ekologiya i ekologicheskaya bezopasnost'. Izdatel'skij centr Akademiya.

Kochurov, B. (1997). Geografiya ekologicheskih situacij (ekodiagnostika territorij). IG RAN, Moscow.

Korkin, S., \& Talyneva, O. (2015). Regional'nye aspekty proyavleniya opasnyh prirodnyh ekzodinamicheskih processov dlya territorii Srednego Priob'ya. In Materialy Vserossijskoj nauchno-prakticheskoj konferencii "VII Shchukinskie chteniya" (pp. 28-31). Moscow.

Likhacheva, E. A., \& Timofeev, D. A. (2004). Ekologicheskaya geomorfologiya. Sloar-spravochnik. Mediya-Press.

Likhacheva, E., Petin, A., Chichagov, V., Chendev, Yu., Bulanov, S., \& Goleusov, P. (2013). Antropogennaya geomorfologiya: nauka i praktika. Geomorfologiya, 88-91.

Milanovich, P. (2000). Geological Engineering in karst. Zebra Publishing Ltd.

Nysanbek, U. (2003). Konceptual'nye problemy ekologicheskoj bezopasnosti v Respublike Kazakhstan. Analytic, 5, 16-17.

Pecsi, M. (1986). Ecological-geomorphological researches Hungary. Budapecht, 117-122.

Sakhiev, S. (2016). Ekologicheskaya bezopasnost' odin iz osnovnyh strategicheskih komponentov nacional'noj bezopasnosti Respubliki Kazakhstan. Almaty.

Shogren, J., \& Grocken, T. (1999). Risk and its consequences. Journal of Environmental Economics and Management, 37(1), 45-51. https://doi.org/10.1006/jeem.1998.1059

Simonov, Yu. (1990). Inzhenernaya geomorfologiya. Indikacionnyj analiz i metody issledovaniya. Izd-vo MGU.

Simonov, Y., \& Gladkevitch, G. (1995). Concept of the ecological certification of territories on the basis of land use structure. In Global Changes and Geography (pp. 112-113). Moscow.

Simonov, Yu., \& Simonova, T. (2013). Fundamental'nye problemy antropogennoj geomorfologii. Geomorfologiya, 3, 3-10. https://doi.org/10.15356/0435-4281-2013-3-3-10

Sturman, V. (2003). Ekologicheskoe kartografirovanie (pp. 170171). Moscow.

Toy, T. J. (1984). Geomorphoiogv of surface-mined lands in Western United States. In J. E. Costa \& P. J. Fleisher (Eds.), Developments and applications of geomorphology (pp. 133-170). Springer. https://doi.org/10.1007/978-3-642-69759-3_5

Vilesov, E., Naumenko, A., Veselova, L., \& Aubekerov, B. (2009). Fizicheskaya geografiya Kazakhstana. Uchebnoe posobie pod obshchej redakciej A. Naumenko. Kazakh universiteti, Almaty.

Voskresensky, I., Suchilin, A., Ushakova, L., Shaforostov, V., \& Entin, A. (2018). Monitoring rel'efa trassy magistral'nogo truboprovoda $\mathrm{v}$ centre Russkoj ravniny s primeneniem distancionnyh i geoinformacionnyh metodov. Vestnik KazNU, ser. Geograficheskaya, 49(2), 50-61.

https://doi.org/10.26577/JGEM.2018.2.510 